\title{
Transformational of Environmental Governance in Malaysia towards Environmental Sustainability
}

\author{
Nur Afrina Qistina Ahmad Halmi, Haliza Abdul Rahman
}

To Link this Article: http://dx.doi.org/10.6007/IJARBSS/v11-i19/11701 DOI:10.6007/IJARBSS/v11-i19/11701

Received: 02 October 2021, Revised: 24 October 2021, Accepted: 20 November 2021

Published Online: 17 December 2021

In-Text Citation: (Halmi \& Rahman, 2021)

To Cite this Article: Halmi, N. A. Q. A., \& Rahman, H. A. (2021). Transformational of Environmental Governance in Malaysia towards Environmental Sustainability. International Journal of Academic Research in Business and Social Sciences, 11(19), 1-13.

Copyright: () 2021 The Author(s)

Published by Human Resource Management Academic Research Society (www.hrmars.com)

This article is published under the Creative Commons Attribution (CC BY 4.0) license. Anyone may reproduce, distribute, translate and create derivative works of this article (for both commercial and non-commercial purposes), subject to full attribution to the original publication and authors. The full terms of this license may be seen at: http://creativecommons.org/licences/by/4.0/legalcode

Special Issue Title: Youth and Community Wellness, 2021, Pg. 1 - 13

Full Terms \& Conditions of access and use can be found at http://hrmars.com/index.php/pages/detail/publication-ethics 


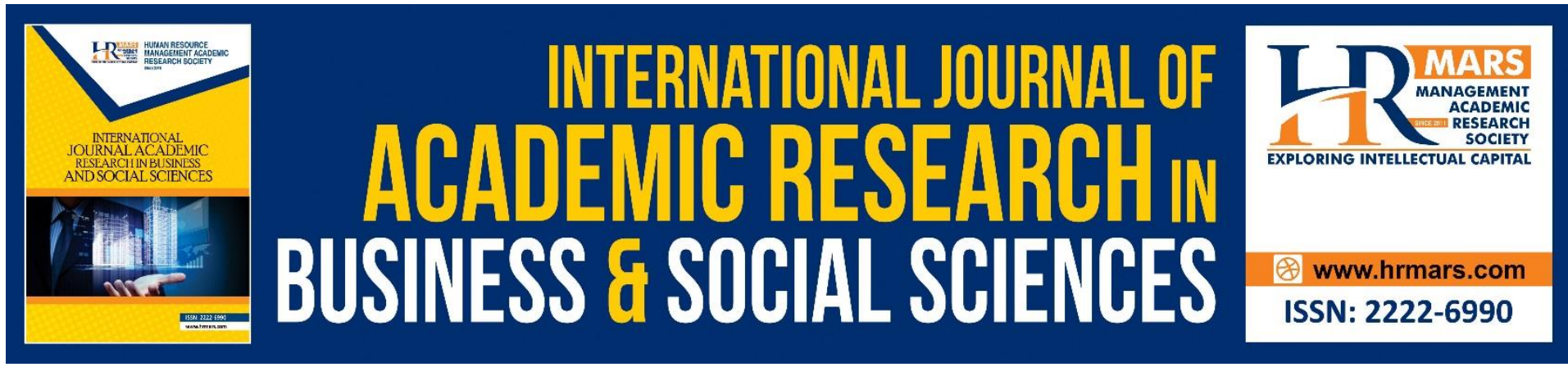

\title{
Transformational of Environmental Governance in Malaysia towards Environmental Sustainability
}

\author{
Nur Afrina Qistina Ahmad Halmi², Haliza Abdul Rahman ${ }^{1,2}$ \\ ${ }^{1}$ Institute for Social Science Studies, Putra Infoport, Universiti Putra Malaysia, 43400 \\ Serdang, Selangor, Malaysia, ${ }^{2}$ Department of Environmental and Occupational Health, \\ Faculty of Medicine and Health Sciences, Universiti Putra Malaysia, 43400 Serdang, \\ Selangor, Malaysia. \\ Email: dr.haliza@upm.edu.my
}

\begin{abstract}
The Environmental Quality Act 1974 (Act 127), which represents the environmental legislation has begun in force and is now more than fourteen years old. The amendment plan (Phase 1) is being made by the Ministry of Environment and Water (KASA) through the Department of the Environment (DOE) where these changes concentrate on compounds and penalties. This amendment would allow strict action against criminals and perpetrators who pollute the climate. Besides, The DOE shall survey the plans to change the number of punishments and penalties which will be levied on offenders and criminals that cause environmental pollution. This paper is to study the transform of EQA 1974 and its effectiveness to protect the environment from various types of pollution. Secondary data are collected about "transformation of environmental governance in Malaysia" scope matters. Malaysian Government currently has introduced Seven Fast-Evolving Technology methods which are; Industry4WRD: National Policy on Industry 4.0, National IoT Strategic Roadmap, Smart City, Big Data Analytics, Robotics, Blockchain and Autonomous car. Among them, the most related to the Environment policy data is on the 'Big Data Analytic'. Therefore, by providing the Big Scale data, Improving the amendment of EQA 1974, focusing on 17 Goals for United Nations Sustainable Development, and Introducing Greentech Malaysia, KASA will curb any environmental issues.
\end{abstract}

Keywords: Pollution, Environmental governance, Ministry of Environment and Water, Environmental Quality Act 1974, Malaysia

\section{Introduction}

Nowadays, the main environmental problems in Malaysia are pollution coming from unsustainable development, industrial activities, agriculture, transportation and the continuous dumping of solid waste. As a rapidly developing country, the industry is the main focus in generating national income. However, various industrial activities especially conventional and illegal ones produce various forms of pollution such as air pollution, water pollution as well as dangerous chemical and toxic waste which contributes to climate change and global warming issues. The results show that most of the air pollution comes from urban 
areas due to industrial emissions, transportation and energy sectors and cross-border air pollution (Ferronato \& Torretta, 2019).

The polluted river is a common cause by the industries and other activities which contribute to water crisis and water shortage issues. Surprisingly, there is no great solution to the water crisis related to river pollution and crisis management especially in Klang Valley, which every year, there is the same issue occur and becomes more complex. Despite a change in the climate patterns, water pollution and increased demand are gradually threatened by the rise of bad weather and natural disasters and by seasonal changes as a result of climate change (Murad \& Pereira, 2019).

In terms of water components, both, point and non-point sources of emissions degrade Malaysian rivers. Main sources of pollution include treatment plants for wastewater, agritourism, production and residential facilities. Practices of underground and land clearing help to sweep the rivers and can be a pollution source both point and pointless (Mei et al., 2016). Other activities or projects that may lead to water contamination include airports, housing, industry, mining, petroleum, energy, resorts, waste treatment and disposal facilities. Pollution is mostly due to storm runoffs after a downpour. Hence, to evaluate the capabilities of the region for extra emissions and the waste management criteria, site adaptability assessment must be carried out for non-prescribed operations.

Additionally, environmental issues such as soil degradation, deforestation and other problems caused by construction or building activities continuously disturb the habitats and natural environment. Energy waste, unsustainable construction waste management, the production of greenhouse gases and soil pollution are among the main form of pollution from this activity. For example, because of these activities, soil degradation will spread space and harm the environment and ecological values. Perhaps, during construction activities, there are increases in air and noise pollution from dust in nearby areas. In addition, pesticides pollution is extensively contaminating the environment due to its uncontrolled usage that degrades soil functions by degrading its biological activity and ability to remove pollutants that result in the reduction of crop yield (Farina et al., 2016). Due to the response of various environmental problems in this country, a few of related legislative were gazettes, namely the Environmental Quality Act 1974, Forestry Act 1984, Biodiversity Act 1998 and Local Government Act 1976 (DOE, 2020), (NATIONAL FORESTRY ACT, 1984), (Biodiversity Act, 1998), (Act 171- Local Government Act, 1979). But, the Environmental Quality Act (EQA) 1974 is the main Act gazette for the prevention, abatement, control of pollution and enhancement of the environment throughout the country. The EQA 1974 was a gazette as early as the year 1974.

Thus, with existing environmental changes in problems and issues, this law can be amended from time to time to fit with the changes taking place. This includes empowering public participation and involvement actively in various environmental related issues to ensure the environmental sustainability of the country. Industrialisation in Malaysia needed to be environmental-friendly by adopting sustainable consumption and production approach. To improve and facilitate sustainable living, a concerted effort by the government, industry players, academicians and the public was vital. Thus, the objective of this paper is to study 
the transform of EQA 1974 and its effectiveness to protect the environment from various types of pollution.

\section{Methods}

This study identified and selected literature on the transformation of environmental governance-related issues in Malaysia. The research was identified from various and related documents such as journals, reports, proceedings, and newspapers. Articles with keywords in their titles or abstracts were selected. This was done for articles published mainly in 20162020. The secondary data are collected about "transformation of environmental governance in Malaysia" scope matters. Malaysian Government currently has introduced Seven FastEvolving Technology methods which are; Industry4WRD: National Policy on Industry 4.0, National loT Strategic Roadmap, Smart City, Big Data Analytics, Robotics, Blockchain and Autonomous car. Among them, the most related to the Environment policy data is on the 'Big Data Analytic'. Therefore, by providing the Big Scale data, Improving the amendment of EQA 1974, focusing on 17 Goals for United Nations Sustainable Development, and Introducing Greentech Malaysia, KASA will curb any environmental issues.

\section{Results and Discussion}

\section{Transformational of Environmental Governance in Malaysia}

\section{i) The Need of Revisions to Environmental Quality Act 1974}

The Ministry of Environment and Water in Malaysia (KASA) is responsible for ensuring the clean, balanced and safe sustainability of the Malaysian environment. The Ministry also acts as an information disseminator for people's thoughts, ideas and expertise to the continuous appreciation of the environment. To carry out this duty, the ministry under the DOE enforced the EQA 1974 throughout the country except for Sarawak State. The EQA 1974, was the first environmental law to control a broad spectrum of environmental problems in this country.

It shows that the complex environmental problems in Malaysia are growing. Thus, the country is responsible for taking big steps to avoid any dangerous environmental changes. In response to that, environmental law is a gazette to resolve environmental concerns in Malaysia as a structured management response. The 1974 EQA, which has begun in force and is now more than fourteen years old, represents the environmental legislation. With various current environmental issues, therefore, it needs changes in management and legislation of EQA 1974 (Eljarrat et al., 2020).

Thus, a change of Phase 1 of 1974 EQA (Phase I) is being made by KASA through the DOE where these changes concentrate on compounds and penalties. This amendment would allow strict action against criminals and perpetrators who pollute the climate. The DOE shall survey the plans to change the number of punishments and penalties which will be levied on offenders and criminals that cause environmental pollution. The survey will collect feedback and information from stakeholders and the public. The time between 16 February 2021 and 1 March 2021 for this survey begins (DOE, 2020). Any changes made to the Act will, however, take time and we must ensure that all parties concerned are engaged in ensuring that the Act is successful. 
By referring to the EQA 1974, several clauses are being proposed to amend concerning the value of penalties. With the among of the clauses being composed, one of in clauses is "Restrictions on pollution of the atmosphere" (S.22), the penalty is suggested to amend by increasing the amount to ten thousand ringgits. Next, is on (S.23) "Restrictions on noise pollution" the amendment on penalty is increased to ten thousand ringgits. Then, on "Restriction on pollution of the soil" (S.24), the penalty is increased to fifty thousand ringgits, this is a huge of amount penalties. Other than that, on (S.25) and (S.27) which "Restrictions on pollution of inland waters" and "Prohibition of discharge of all into Malaysian waters" the fines are also not less than fifty thousand ringgits. Then, on (S.29) "Prohibition of discharge waste into Malaysian waters" and lastly, on (S.29A) "Prohibition of open burning will get a penalty punishment more than 10 thousand ringgit".

A determination of legislative measures in protecting the environment for future development is needed. As stated, Malaysia has environmental and compliance legislation, but the environmental problem will become worse without being curb and improved. According to Maketab Mohamed, former chairman of the Malay Nature Society (MNS), the government required a modification of the Waste and Industrial laws and the government need to plan and amend the EQA 1974 with a new Act to expand the regulatory powers and prosecute those polluting the environment more seriously (Mohamed, 2014). The former Minister of Energy, Science, Technology, Environment and Climate Change, Yeo Bee Yin also supports the declaration that legislation and legislative powers would be the subject of the proposed law (Esther Landau, 2019). The Government should simplify compliance and legal processes to facilitate the sanction of people who commit crimes against the environment.

Currently, the government was committed to ensuring that Malaysians get to enjoy a cleaner and healthier environment. Thus, the government needs to amend the EQA 1974 from time to time to boost enforcement action and legislative powers. It would see greater enforcement powers as well as stiffer punishments meted out to those who pollute the environment.

\section{ii) Current Initiatives Environmental Program}

The challenge now was to restore economic activities without reactivating environmental degradation. According to that, several activities are done by the DOE to curb the current issue:

1. The Department will implement enforcement with the 2005 Scheduled Waste System (eSWIS) on Environmental Quality. Any waste generator convicted of any violation of this regulation is liable to a RM 2,000.00 penalty for each breach (EQA 1974).

2. Create activity by following the Environmental Friends (RAS) Activities. Awareness raising and mobilising community members of each parliamentary constituent was created for Friends of Nature, to protect the environment and avoid environmental degradation and pollution activities. The Department also provides online services for public dealing.

3. The Department is now launching a new edition of MyIPU, in line with the Government's continuing commitment to improving the quality of services to 
people. It contains general information on Remote Sensing Agency, Hotspot (NOAA20), Fire Danger Rating System, Weather Department, Health Ministry and Extreme Weather in the IPU system. The framework also includes the new API reading. This is one of the strategic DOEs that promote the community's use of technology. In addition, this online application is one of the means of enhancing the relationship between issues and concerns that must be addressed as soon as possible (DOE, 2020).

\section{iii) Environmental Act Related to The Data}

The government of Malaysia has introduced Seven Fast-Evolving Technology methods which are; Industry4WRD: National Policy on Industry 4.0, National IoT Strategic Roadmap, Smart City, Big Data Analytics, Robotics, Blockchain and Autonomous car. Among them, the most related to the Environment policy data is on the 'Big Data Analytic'. The Ministry of Environment and Water in Malaysia is responsible to understand what is the purpose of "Big Data Analytics" towards the environment.

The goal of 'big data research' is:

1. Enhance decision-making processes so that government programs can be more strategic designed and tracked more effectively.

2. Implement an analysis of data to gain insight into the delivery mechanism of government service which is descriptive, diagnostic, predictive and prescriptive. Incorporate and educational capacities of public authorities in the area of data science.

3. Maximize the use and exchange of government and social media data to create a community of different forms of creativity powered by data.

The data analysis consists of several phases. Firstly, the data would recognize any environmental issues. The method then analyses the problem and visualises it. Once the data has generated the problem, any environmental changes in Malaysia are easily seen and understood by the management. There is a battle to curb any environmental crisis until the first problem is solved. Solutions between the public need and those who have served as an environmental officer. Artificial intelligence is one of the ways the environmental officer can track and resolve environmental change, such as large-scale data analysis.

EIA obligation is a crucial prerequisite for procedural involvement in public, where the standards of the previous notice and consultancy are theoretically being followed in good faith, and even prior informed consent before such practices are implemented (Section 34A, EQA 1974). To have access to the EIA report following a Detailed EIA (now recommended Environmental Quality Schedule activities) and to eliminate and minimise environmental risks associated with a planned transaction (Prescribed Activities). In EIA there is 2015 Order (Environmental Impact Assessment) sets out the way to enforce and apply the preliminary notice theory (Lee, 2010). In such studies, reference to a proposed activity likely to result in harm to the environment is communicated, in the process of its approval, to the public in general and to the stakeholders concerned, where public opinions and objections, as well as associated stakeholders concerning the proposed activity, may be considered (Rizqa \& Abusharar, 2014). The DOE has launched the program 'Directed Self-Regulation, to develop an industrial society that practices its culture of pride in environmental excellence (GSR). 
Next, $100 \%$ compliance tests for licensed facilities, manufacturing industries and sewage facilities can be strengthened by field, inspection and involvement in the industrial sector activities. The survey on the control sector consists of methods for control and self-regulation, i.e., verification of the mainstreaming environmental instruments. To help the regulated population, achieve the self-regulation status. The DOE has established a range of environmental mainstreaming tools (EMTs).

The methods for mainstreaming environmental protection (EMT) include Environmental Policy, Environmental Budgeting; Environmental Monitoring Committee; Environmental Facility, Environmental Competency, Environmental Reporting and Communication and Environmental Transparency.

\section{Air Pollution Index}

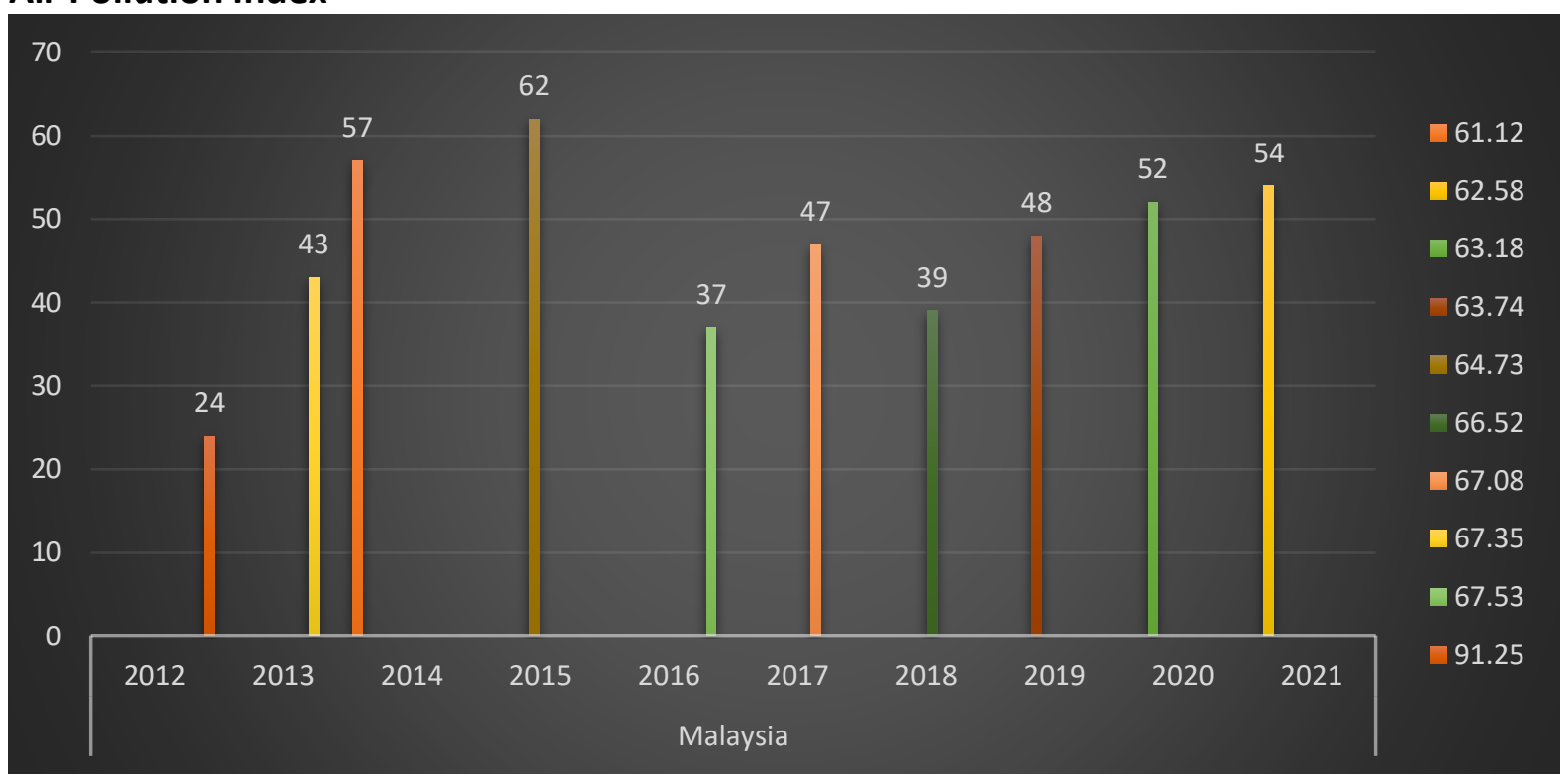

Figure 1: API Ranking year 2012 to 2021(DOE, 2020)

Table 1: API ranking Data (DOE, 2020)

\begin{tabular}{|l|l|l|c|}
\hline YEAR & RANK & COUNTRY & POLLUTION INDEX \\
\hline 2021 & 54 & Malaysia & 62.58 \\
\hline 2020 & 52 & Malaysia & 63.18 \\
\hline 2019 & 48 & Malaysia & 63.74 \\
\hline 2018 & 39 & Malaysia & 66.52 \\
\hline 2017 & 47 & Malaysia & 67.08 \\
\hline 2016 & 37 & Malaysia & 67.53 \\
\hline 2015 & 62 & Malaysia & 64.73 \\
\hline 2014 & 57 & Malaysia & 61.12 \\
\hline 2013 & 43 & Malaysia & 67.35 \\
\hline 2012 & 24 & Malaysia & 91.25 \\
\hline
\end{tabular}




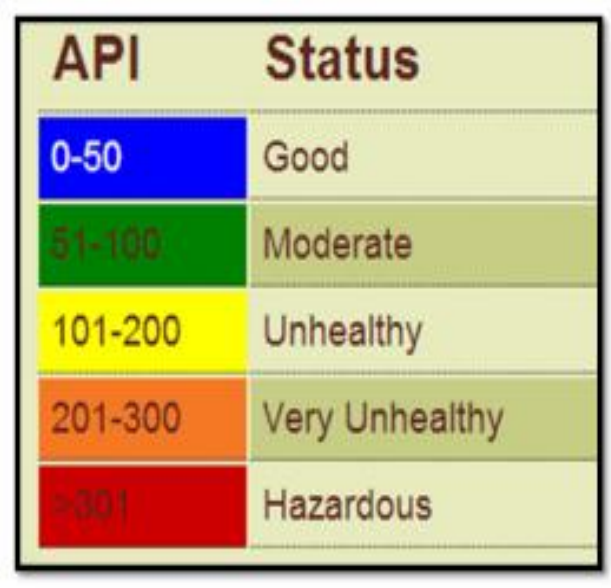

Figure 2: Air Pollution Index Flow Chart Source: (DOE, 2020)

The Figure 1 and 2 represent the API ranking from the year 2012 to 2021 . As we can see in the figure, the lowest ranking means it is in a good position. But, from the year 2019 until 2021 Malaysia is ranked 50th and above. That is means, the KASA has moderate management in dealing with air quality problems. Malaysia was ranked 24th in the world rankings in 2012 which is the top ranking among the years. Thus, this figure shows that DOE should revise what activities were carried out in the year 2012 which caused the position to rank 23rd. The Air Pollutants Index (API) determines the assessment of air quality in Malaysia (API). The API is designed to report air quality rather than the current air pollutant concentration in a way that can clearly explain the spectrum of values. This index also illustrates its impact on human health between positive and harmful and can be categorised following the NHP action standards. The Malaysian API scheme is very similar to the US-EPA1 Pollutant Efficiency Index (US-EPA) (PSI).

\section{iv) Integrated Environmental Policy}

Environmental Policy Integrated (EPI) is the method in which environmental issues are positioned at the centre of decision-making in other sectoral policies such as energy and agriculture, instead of the separate direction by environmental policy instruments alone. There are five overall objectives of integrated environmental Policy, namely; encouraging stakeholders, reducing biodiversity pressure and protecting ecosystems, species and genetic diversity; ensuring that the advantages of using and capabilities are shared equally and reasonably by all stakeholders. The five goals come together with 17 national biodiversity targets, which will be accomplished in the future (NSHAP, 2017).

The goals include all major aspects of biodiversity conservation, including awareness, integrating biodiversity, introducing good management practices in various fields, enhancing our areas covered, preventing the extinction of species and bio-safety. The goals also focus on capacity building, awareness building and improvement in financing (Noor Azizah and Zanaton, 2015). There are a set of activities followed with each goal that details the steps to be taken to meet the goals and eventually the goals. A total of 57 programs are covered by 
this regulation. The principal metrics to measure success are all observed in all interventions. The lead agencies and the key collaborators have also been named for all acts. Too much progress in the resolution of the problems of "traditional" human capital and the creation of appropriate financial systems and the growth of protected areas. The main emphasis in the national development policy, plan and programs (PPP) is the study of many mainstreaming approaches - strategic environmental assessment, the approach to habitats and rural landscape and financial instruments (Khairilmizal et al., 2016).

In the next 20 years, more Malaysians are a crucial factor, but also, they need to develop and conserve healthy biodiversity. Furthermore, at least $20 \%$ of land and inland waters and $10 \%$ of coastal and marine areas are preserved through the Representative Protected Areas System as well as other productive area management measures by 2040 . Properly preserved and restored fragile habitats and living environments, particularly calcareous hills, humid areas, coral reefs and marine beds. Significant terrestrial and marine ecological corridors have been created, restored and preserved.

The extinction of known endangered species has been avoided and their conservation has been consolidated and maintained. It was developed under regulation and dramatically reduced contraband, illegal harvesting and trafficking in animals, fisheries and plants. It will define invasive aliens' species and pathways, regulate priority species, and take measures to prevent them from being introduced and produced. A global biosafety program, including the liability and redress framework, is in place to handle the potential adverse impacts of modern biotechnology on biodiversity and human health.

The genetic diversity of crops, farmed and domesticated animals and wild families are adequately preserved. Malaysia has a Nagoya protocol on the access to genetic capital and equal benefit sharing consistent with $A B S$ operating frameworks. CBD and related MEAs have increased their ability to incorporate national and sub-national biodiversity policies considerably. Major knowledge and science creation and application are based on biodiversity, its values, it is working, its status and patterns, as well as the consequences of its loss. In conclusion, funding and services for the protection of biodiversity will be greatly extended by 2040 from government and non-government sources (Grant and Booth, 2009).

\section{v) The Way Forward and Suggestion}

Malaysia, along with 192 other international leaders, adopted the 2030 Agenda for Sustainable Development (2030 Agenda) on September 25, 2015, at the United Nations General Assembly in New York. With 17 Goals (SDGs) and 169 targets, this is a global commitment to more sustainable, resilient, and inclusive development. (Programme, 2021). The SDGs, also known as the Global Goals, were adopted as a universal call to action to end poverty, protect the planet and ensure that all people enjoy peace and prosperity by 2030 . The 17 SDGs are integrated that is, they recognize that action in one area will affect outcomes in others and that development must balance social, economic and environmental sustainability. Achieving the SDGs requires the partnership of governments, the private sector, civil society and citizens alike to make sure Malaysian leave a better planet for future generations. Malaysia recognises that comprehensive SDG implementation will necessitate the mobilisation of resources such as workforce, building capacity, physical spaces, and funding. Because Malaysia's national development plan has 
always prioritised the economic, social, and environmental agendas, SDG implementation in Malaysia is coordinated with the five-year national development plan, which is funded by the government development budget. As a result, resource allocation and funding are readily available.

The alignment of SDGs and national development is accomplished through a mapping exercise that involves mapping the action plans, initiatives, and outcomes of the national development plan to the SDGs' goals, targets, and indicators. The mapping exercise begins with the Eleventh Malaysia Plan (11MP), 2016-2020, and continues with the Mid-Term Review (MTR) of the Eleventh Malaysia Plan (11MP), 2018-2020, and then with the Twelfth Malaysia Plan (12MP), 2021-2025, and the Thirteenth Malaysia Plan (13MP), 2026-2030 (Unit, 2021). The mapping of SDGs with the strategic thrust of the 11th Malaysia Plan and the six policy pillars of the 11MP MTR. SPV 2030 (Shared Prosperity Vision) was announced in 2019 (Government Policies, 2019). The 12MP, which covers three development dimensions economic empowerment, environmental sustainability, and social reengineering - will help to solidify the SPV 2030's implementation. SPV 2030's underlying principle is economic growth through "equitability of outcome," and it outlines eight enablers, seven strategic thrusts, and 15 guiding principles.

Malaysia takes pride in presenting a Voluntary National Review (VNR) at the 2017 global High-level Political Forum (HLPF) in support of the Agenda's global monitoring and reporting and is committed to broader country reporting every four years (Malaysia Prime Minister's Department, 2017). This is Malaysia's first VNR under the 2030 Agenda. Furthermore, in September 2019, Malaysia hosted the Malaysia SDG Summit 2019 themed "The Whole of Nation Approach: Accelerating Progress on the SDGs" to raise public awareness and understanding of the SDGs while also providing a forum for stakeholders to discuss progress, opportunities, challenges, and solutions, for example, the public and private sectors, academia, and non-governmental organisations are all represented (Unit, 2021). The event demonstrated Malaysia's commitment to bringing together a diverse range of stakeholders to assess SDG progress and gaps, as well as to explore ideas and solutions to bridge these gaps. This platform is critical for bridging gaps, and the summit was not intended to be a one-time event, but rather to serve as a catalyst for future dialogues and collaborations across sectors to ensure that we all achieve the 2030 Agenda. 


\section{Goals for United Nations Sustainable Development}
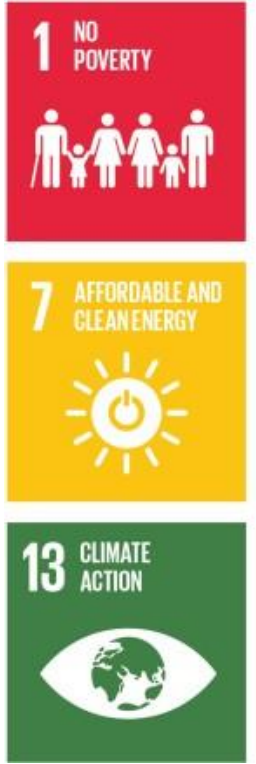
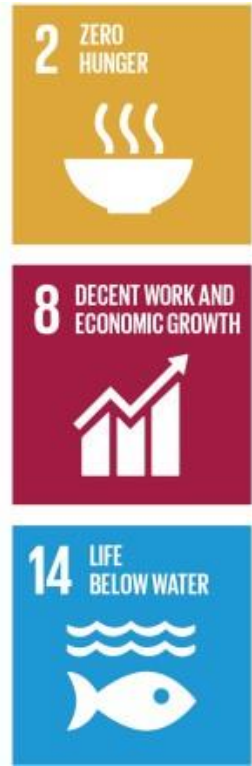
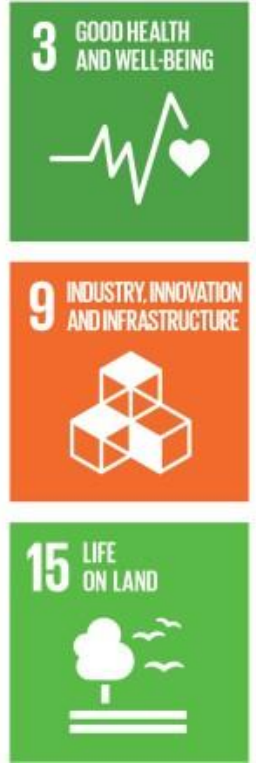
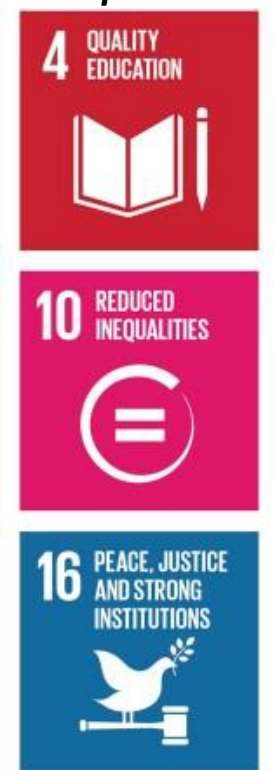
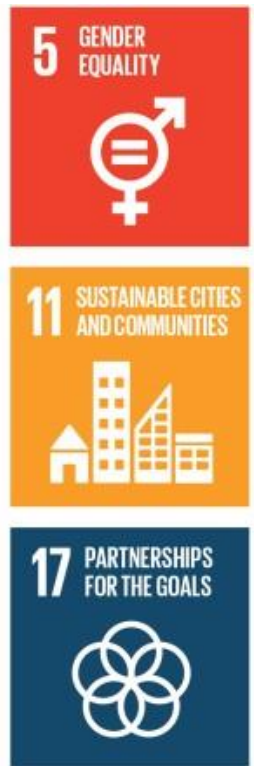
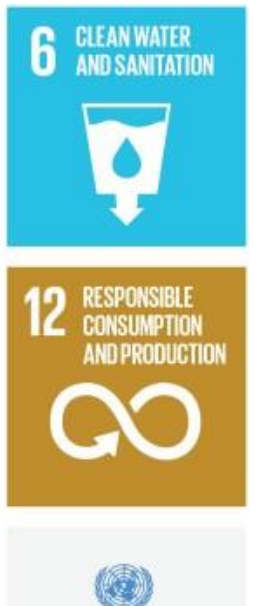

SUSTAINABLE DEVELOPMENT GË.". ALS

Figure 3: 17 Goals for United Nations Sustainable Development

Malaysia takes pride in presenting a Voluntary National Review (VNR) at the 2017 global Highlevel Political Forum (HLPF) in support of the Agenda's global monitoring and reporting and is committed to broader country reporting every four years. This is Malaysia's first VNR under the 2030 Agenda. Furthermore, in September 2019, Malaysia hosted the Malaysia SDG Summit 2019 themed "The Whole of Nation Approach: Accelerating Progress on the SDGs" to raise public awareness and understanding of the SDGs while also providing a forum to discuss progress, opportunities, challenges, and solutions with various stakeholders, including the public and private sectors, academia, and civil society and non-government organisations.

The event demonstrated Malaysia's commitment to bringing together a diverse range of stakeholders to assess SDG progress and gaps, as well as to explore ideas and solutions to bridge these gaps. This platform is critical for bridging gaps, and the summit was not intended to be a one-time event, but rather to serve as a catalyst for future dialogues and collaborations across sectors to ensure that we all achieve the 2030 Agenda. In 17 goals for United Nations Sustainable Development, there are 8 goals related to the Environmental Plan Management, which are Clean Water and Sanitation; Affordable and Clean Energy; Industry, Innovation and Infrastructure; Sustainable Cities and Communities; Responsible Consumption and Production; Climate Action; Life Below Water and finally Life on Land.

Furthermore, the execution and production of action plans; a constructive approach to regional and global environmental issues; and the improvement of administrative and institutional mechanisms are the seven major areas that involve strategies to improve environmental policy. Pollution prevention and management, as well as ecosystem degradation Growth planning and execution that is integrated. Natural and environmental management that is effective. Finally, it is critical to raise awareness and educate Malaysians. The KASA also introduce the Functionality of Greentech Malaysia to increase the environmental performance by:

- Implementation Department for Green Technology

- Global Head of Green Technology Growth Manager 
- Encourage green technology programs and projects

- Specifications and database focal point

- Alignment of national green technology policy research, development and implementation

Thus the policies must look at how the influence of renewable energy technologies is contrasted with fossil fuels and the potential for energy efficiency improvements, to establish sound policies (Press, 2020).

\section{Conclusion}

The knowledge of the potential environmental impacts of renewable energy technology is also necessary to detect and follow the design, production processes, project sites, utility activities. Usually, the environmental effects of energy sources may be calculated at two scales or accumulation stages. The first level is at the regional or national level that seeks broad similarities and planning reasons for describing the typical plant or installation's average impact. For example, the purpose of life-cycle evaluations, such as extracting raw material, decaying plants and disposal of equipment, is to consider the entire range of impacts related to any energy project phase. On the second scale, local effects, such as impacts on biodiversity and water supplies, can be assessed at the site level. Therefore, by providing the Big Scale data, Improved the amendment of EQA 1974, focusing on 17 Goals for United Nations Sustainable Development, and Introduce Greentech Malaysia, KASA will curb any environmental issues in Malaysia and indirectly Malaysia will get top $10^{\text {th }}$ world rank in the Air Pollution Index as targeted.

\section{References}

DOE. (2020). ENVIRONMENTAL QUALITY ACT, 1974 (Act 127) ARRANGEMENT OF SECTIONS. 1974(Act 127).

https://www.env.go.jp/en/recycle/asian_net/Country_Information/Law_N_Regulatio n/Malaysia/Malaysia_mal13278.pdf

Eljarrat, E., Li, F., Jahangir Alam, M., Stavropoulou, E., Manisalidis, I., Stavropoulos, A., \& Bezirtzoglou, E. (2020). Environmental and Health Impacts of Air Pollution: A Review. Frontiers in Public Health / Www.Frontiersin.Org, 8, 14. https://doi.org/10.3389/fpubh.2020.00014

Landau, E. (2019). Yeo: New act needed to replace Environmental Quality Act 1974. New Straits Times. https://www.nst.com.my/news/nation/2019/05/484931/yeo-new-actneeded-replace-environmental-quality-act-1974

Farina, Y., Abdullah, P., Bibi, N., \& Khalik, W. M. A. W. M. (2016). Pesticides Residues in Agricultural Soils and Its Health Assessment for Humans PESTICIDES RESIDUES IN AGRICULTURAL SOILS AND ITS HEALTH ASSESSMENT FOR HUMANS IN CAMERON HIGHLANDS, MALAYSIA (Residu Racun Serangga dalam Tanah Pertanian dan Penilaian Kesih. Malaysia Journal of Analytical Sciences, 20(6)(December 2016), 1346-1358. https://doi.org/10.17576/mjas-2016-2006-13

Ferronato, N., \& Torretta, V. (2019). Waste Mismanagement in Developing Countries: A Review of Global Issues. International Journal of Environmental Research and Public Health, 16(6). https://doi.org/10.3390/IJERPH16061060

Government Policies. (2019, October 7). Shared Prosperity Vision 2030. Prime Minister's Office of Malaysia. https://www.pmo.gov.my/2019/10/shared-prosperity-vision-20302/ 
Grant, M. J., \& Booth, A. (2009). A typology of reviews: An analysis of 14 review types and associated methodologies. Health Information and Libraries Journal, 26(2), 91-108. https://doi.org/10.1111/j.1471-1842.2009.00848.x

Khairilmizal, S., Hussin, M. F., Husna, A. K., Hussain, A. R., Jusoh, M. H., \& Sulaiman, A. A. (2016). Implementation of disaster management policy in Malaysia and its compliance towards international disaster management framework. Information (Japan).

Lee, O. A. (2010). Coastal resort development in Malaysia: A review of policy use in the preconstruction and post-construction phase. Ocean \& Coastal Management, 53(8), 439446. https://doi.org/10.1016/j.ocecoaman.2010.06.010

Act 171- Local Government Act 1979, Law of Malaysia (2006).

NATIONAL FORESTRY ACT 1984, 75 (1984).

Malaysia Prime Minister's Department, E. P. U. (2017). Malaysia Sustainable Development Goals Voluntary National Review 2017. In High-level Political Forum.

Mei, N. S., Wai, C. W., \& Ahamad, R. (2016). Environmental Awareness and Behaviour Index for Malaysia. Procedia - Social and Behavioral Sciences, 222, 668-675. https://doi.org/10.1016/j.sbspro.2016.05.223

Mohamed, M. (2014). Expedition promotes preservation of biodiversity in Malaysia. Vale. http://www.vale.com/mozambique/EN/aboutvale/news/Pages/expedicao-valoriza biodiversidade-na-malasia.aspx

Murad, M. W., \& Pereira, J. J. (2019). Malaysia: Environmental health issues. Encyclopedia of Environmental Health, 194-210. https://doi.org/10.1016/B978-0-12-409548-9.11529-5

Press, T. N. A. (n.d.). The Power of Renewables: Opportunities and Challenges for China and the United States. Retrieved February 21, 2021, from https://www.nap.edu/read/12987/chapter/6

Programme, U. N. D. (2021). Sustainable Development Goals / United Nations Development Programme. UNDP.

https://www.undp.org/sustainable-developmentgoals?utm_source=EN\&utm_medium=GSR\&utm_content=US_UNDP_PaidSearch_Bra nd_English\&utm_campaign=CENTRAL\&c_src=CENTRAL\&c_src2=GSR\&gclid=CjOKCQjwi NSLBhCPARIsAKNS4_c531vBaVwXiz9T65ILHdgzNhnxf3tmlx_ymrSAwp2UpeD9Is2gc5

Rizqa, E. Y., \& Abusharar, S. W. (2014). An Assessment of the Impacts of Construction Projects on the Environment in the Gaza Strip. 6(11), 1-13.

Unit, M. E. P. (2021). Sustainable Development Goals / Official Portal of Economic Planning Unit. Official Portal of Economic Planning Unit, Prime Minister's Department. https://www.epu.gov.my/en/sustainable-development-goals 